DOI https://doi.org/10.18551/rjoas.2020-11.02

\title{
THE ROLE OF ORGANIZATIONAL COMMITMENT IN MODERATING THE RELATIONSHIP OF SELF-EFFICACY ON EMPLOYEE PERFORMANCE
}

\author{
Sutyawan I Kadek Evan*, Riana I Gede, Surya Ida Bagus Ketut \\ Faculty of Economics and Business, University of Udayana, Bali, Indonesia \\ *E-mail: evansutyawan38@gmail.com
}

\begin{abstract}
An employee performance is a result of work achieved in both quantity and quality by an employee. The employee performance can be influenced by employee self-efficacy and organizational commitment. The purpose of this study is to analyze the effect of self-efficacy on employee performance with organizational commitment as a moderating variable. This study took a sample of employees at a five star hotel in Ubud Bali as many as 144 respondents. The collected data were analyzed using moderation regression analysis (MRA) technique. The result of the analysis informs that self-efficacy has a significant effect on employee performance. Moreover, organizational commitment has a significant effect on employee performance. Furthermore, organizational commitment can strengthen the effect of self-efficacy on employee performance. The implications of this study indicate that building organizational commitment of employees is necessary because it is proven to be able to strengthen the effect of self-efficacy on employee performance.
\end{abstract}

\section{KEY WORDS}

Self-efficacy, organizational commitment, employee, performance.

Tourism competition currently happens globally which is marked by some changes in economic conditions causing organizations to restructure to make changes (Jeffrey et al., 2017). Human resources (HR) are one of the important elements in organizational change in order to survive in the era of globalization. Economic changes cause a phenomenon in which the tourism industry does not only focus on predetermined targets, but also begins to pay attention to organizational development to be sustainable, by placing reliable human resources as human capital (Aboramadan et al., 2020). HR is a resource that is used to synergize other resources (Dian, 2016) to be useful in achieving organizational goals (Pasha et al., 2017). Its role is very big in achieving organizational success, especially employee performance in service. Organization always tries to improve employee performances in order to achieve the organizational goals (Berry, 2020)). Employees do not only take a role as objects in achieving goals (Aboramadan et al., 2020), but also become subjects or actors. $\mathrm{HR}$ can be a planner, implementer and controller who plays an active role in realizing the organizational goals; moreover, it has thoughts, feelings and desires that can influence attitudes towards work (Putri and Wibawa, 2016).

The role of HR as one of the most important assets of an organization is not only seen from work productivity but also from the quality of work; hence, it deserves the attention of the organization. Robbins and Judge (2012: 112) state that the employee performance as the ability of doing the employees' job in accordance with their skill. The employee performance depends on the ability of employees to carry out assigned tasks; therefore, some clear and measurable criteria are needed (Wulantika \& Ayuningtias, 2020). The performance is a multidimensional concept including three aspects: attitude, ability and accomplishment. Meanwhile, Diamantidis and Chatzoglou, (2019) says that performance is the result of a planned work process at a certain time. The employee performance is the overall result while carrying out tasks, such as work performance standards and criteria targets, and has been mutually agreed upon (Em and Mukhlis, 2016). It is not just information to do promotions or wage increase, but can motivate employees and develop a plan to improve performance as well (Çetin \& Aşkun, 2018). Moreover, it can be enhanced 
by developing self-efficacy and increasing organizational commitment which impacts the interpersonal of employees to improve the performance of the work (Mustafa et al., 2019).

Diamantidis and Chatzoglou, (2019), states that the employee performance is influenced by intrinsic and extrinsic factors. One of the intrinsic factors is self-efficacy (Kreitner and Kinicki 2014: 169), which is a person's belief about their chances of successfully achieving certain tasks. Individuals with a high self-efficacy tend to achieve better performance due to a strong motivation, clear objectives, stable emotion and ability to deliver top performance with a successful activity. Bandura (1991: 42) states that the selfefficacy reflects an individual's belief in his ability to carry out tasks at specific performance levels. Besides, self-efficacy is a belief that arises because of self-confidence in one's ability to carry out work in achieving success (Saraswati et al., 2017). The self-confidence is related to support and motivation to be more confident of one's own abilities. The self-efficacy is very much needed in employees to improve their ability to do their assigned tasks so that the organization runs optimally (Kim and Christopher, 2018). The self-efficacy is required to make the employees able to work well and have high performance. Belief in self-efficacy means that the employee believes of achievement obtained which makes employees work harder and always want to produce the best so that they can improve individual performance (Laura, 2017). The other research (Iroegbu 2015; Marsudi, 2017) state that self-efficacy that is developed and driven by the organization has a significant effect in improving employee performance (Downes et al., 2020).

Beside self- efficacy, an organizational commitment is one of the key in maintaining the performance of employees (Maria, 2014). Luthans (2011: 112) defines the organizational commitment as an attitude that reflects the organizational employee loyalty and is an ongoing process whereby organizational members express their concern to the organization, organizational success and sustainable progress. The organization will run well when it js supported by self-efficacy and organizational commitment (Yulan, 2017). Saraswati et al. (2017) state that organizational commitment is a measure of the strength of employee identity and involvement in organizational goals and values. A number of researchers (Salman et al., 2016; Machmud, 2018) state that self-efficacy can significantly improve employee performance. The other researchers have also found that organizational commitment has an influence on employee performance (Maria, 2015; Saraswati et al., 2017; Yulan, 2017). Furthermore, Pasha et al. (2017) share the same understanding that organizational commitment significantly improves employee performance. The organizational commitment is also seen to have a significant relationship with employee productivity and self-efficacy (Yulan, 2017). Pasha et al. (2017) describe self-efficacy as a motivating concept that has a close relationship with organizational commitment in improving employee performance. The commitment of organizational is described as the desire of the members towards their work within the organization as well as how to express themselves in the cognitive and emotional work. The organizational commitment and employee self-efficacy can assist organizations in encouraging employee performance (Maria, 2014). This study aims to analyze the effect of self-efficacy on employee performance with organizational commitment as a moderating variable.

\section{LITERATURE REVIEW}

This study adopts the theory of expectation as the strength of a tendency to act in a certain way depending on the strength of an expectation that the action will be followed by the existing results. Expectancy theory, proposed by Vroom (1964: 48), emphasizes on factors of the results (outcomes) that involves feelings commonly called self-efficacy in terms of positive, neutral or negative of an object. The components of the theory of expectation consist of the belief and knowledge owned by the object, so that they behave in a certain way to produce good performance (Stevani and Jafar, 2017). Robbins and Judge (2012: 117 ) say that the performance of the results is achieved because of being motivated and satisfied by the work done by the employee. An individual tends to be exposed to things that may not previously be suspected in the process of achieving the desired needs to work 
through the experience of employees in their progress in life. The employee performance is the successful completion of the task undertaken by individuals, as what has been set and measured by supervisor or organization to be accepted with existing standards efficiently and effectively by utilizing the available resources in a change (Hasibuan, 2016: 67). Aboramadan et al., (2020), explains that performance measurement is directed at six indicators, namely: work results, level of quantity and quality that has been produced, and extent to which supervision is carried out. Job knowledge is a level of knowledge associated by the job task that is asked to directly affect the quantity and quality of work results. Initiative is a level of initiative while carrying out work tasks, especially in terms of handling problems that are arise.

Furthermore, Steven et al. (2015) state that self-efficacy is a form of belief that a person has in the ability to increase life achievement. Self-efficacy is a variable that can directly affect performance. Bandura (2010: 42-46) suggests that individual self-efficacy can be seen from three indicators, namely: the level of difficulty of individual self-efficacy in doing a task which differs in the level of difficulty of the task, generality which relates to individual mastery of the field or job duties, and strength which emphasizes the level of strength or stability of the individual against his beliefs. Luthans (2011: 112) defines organizational commitment as an attitude that reflects the organizational and employee loyalty and also as an ongoing process in which organizational members express their concern on organizational, organizational success, and continuous progress (Yulan, 2017). A number of academics define organizational commitment in different but similar ways. Meyer \& Allen (2004: 216) explain that there are three dimensions of organizational commitment, namely: affective commitment, employee emotional attachment, and organizational involvement. Continuous commitment is commitment based on the losses associated with the leaving of the employees from the organization. This may be due to losing seniority over promotions or benefits. Normative commitment is the feeling of being obliged to remain in the original organization because it has to be, that action is the right thing to do.

Mustika and Widyawati, (2020), explains that an important step of self-efficacy is in maintaining employee performance. The employee who has self-efficacy is believed to be a major investment of the organization and give reasons why organizations need to maintain performance in the organization. Several studies have stated that self-efficacy has a significant effect on improving employee performance. A number of researcher (Manasseh, 2015; Marsudi, 2017) state that self-efficacy has a significant effect in improving employee performance. Siagian (2013: 112) states the employee who has the organizational commitment plays an important role in increasing the participation of employees to support a profitability of the organizations. The organizational commitment is the nature of an employee who has a sense of awareness by showing a good performance of the organization and always maintains to improve the progress of the organization. Several studies state that organizational commitment has a significant effect in improving employee performance. The studies proposed by Maria (2015) and Yulan (2017) find that organizational commitment significantly affects the improvement of employee performance. Expectancy theory explains that every employee who carries out their job tends to be based on their organizational commitment. The supports of inner mental attitude and employees are able to foster a positive attitude or self-efficacy with self-dependency to help carry out the work properly. Pasha et al. (2017) mentioned that organizational commitment is able to moderate the effect of self-efficacy on employee performance. Furthermore, Yulan (2017) states that organizational commitment is able to strengthen the relationship between self-efficacy and employee performance.

$\mathrm{H}_{1}$ : Self-efficacy has a significant and positive effect on employee performance;

$\mathrm{H}_{2}$ : Organizational commitment has a significant and positive effect on employee performance;

$\mathrm{H}_{3}$ : Organizational commitment moderates the effect of self-efficacy on employee performance. 


\section{METHODS OF RESEARCH}

This study is quantitative paradigm and associative in a form of causal relationship. Associative research was used to determine the influence of or relationship between two or more variables (Sugiyono, 201 7: 05). The location of the research was conducted at Mandapa Rizt Calton Ubud Bali, which is one of the businesses in the tourism sector which is located at Jl. Raya Kedewatan No.Banjar, Kedewatan, Ubud, Gianyar Regency. The reason of choosing this location as a place of research was because of the discovery of internal organizational problems related to employee performance which are influenced by several factors, namely weak self-efficacy of employees in supporting employee performance and a lack of employee attachment to the organization which is indicated by low employee organizational commitment. This study focused on the study of self-efficacy, organizational commitment, and employee performance. The independent variable in this study is selfefficacy $(X)$, the dependent variable is employee performance $(Y)$ and the moderating variable is organizational commitment $(\mathrm{M})$.

This study used quantitative and qualitative data such as the number of employees and data directly obtained from employees by distributing questionnaires. The qualitative data includes a brief history of the organization, its structure and job descriptions. The data sources of the study were primary and secondary such as observations through questionnaires distributed and direct observation. Primary data was obtained from people or documents. Meanwhile, secondary data is was in the form of organization existence, brief history, number of employees, and organizational structure. The data that had been collected was then analyzed. The research sample was 144 employees who answered each statement in the research questionnaire. The data analysis technique used in this study was the Moderated Regression Analysis (MRA) test, which was a special application of multiple linear regression, where the regression equation contained an element of interaction (multiplication of the moderating variable with the independent variable). MRA can explain moderating variables to strengthen or even weaken the relationship between the independent and dependent variables (Suyana, 2016).

\section{RESULTS OF STUDY}

Table 1 presents that each variable indicator has a person correlation value which is greater than 0.30, so this means that the questions used are appropriate to be used to measure what should be measured, and can reveal data from the variables studied accurately. Thus, the instrument has been declared to have sufficient validity.

Table 1 - Summary of Validity Test Results

\begin{tabular}{lllll}
\hline No. & Variable & Indicator & Correlation & Information \\
\hline 1 & Self-efficacy $(\mathrm{X})$ & $\mathrm{X} 1.1$ & 0.773 & Valid \\
& & $\mathrm{X} 1.2$ & 0.760 & Valid \\
& & $\mathrm{X} 1.3$ & 0.851 & Valid \\
\hline 2 & Organizational commitment $(\mathrm{M})$ & $\mathrm{M} 1.1$ & 0.832 & Valid \\
& & $\mathrm{M} 1.2$ & 0.807 & Valid \\
& & $\mathrm{M} 1.3$ & 0.817 & Valid \\
\hline 4 & Performance $(\mathrm{Y})$ & $\mathrm{Y} 1$ & 0.743 & Valid \\
& & $\mathrm{Y} 2$ & 0.695 & Valid \\
& & $\mathrm{Y} 3$ & 0.695 & Valid \\
& & $\mathrm{Y} 4$ & 0.749 & Valid \\
& & $\mathrm{Y} 5$ & 0.609 & Valid \\
& & $\mathrm{Y} 6$ & 0.730 & Valid \\
\hline
\end{tabular}

Meanwhile, Table 2 shows that the Cronbach's Alpha value for each variable is $>0.6$, (Ghozali, 2011), which means that the measuring instrument will provide consistent results if the measuring instrument is used again to examine the same object; in other words, the variable which is measured has adequate reliability. 
Table 2 - Reliability Test Results

\begin{tabular}{llll}
\hline No. & Variable & Cronbach's Alpha & Information \\
\hline 1 & Self-efficacy $(\mathrm{X})$ & 0.707 & Reliable \\
2 & Organizational commitment $(\mathrm{M})$ & 0.748 & Reliable \\
3 & Performance $(\mathrm{Y})$ & 0.790 & Reliable \\
\hline
\end{tabular}

Furthermore, the test result of Moderating Regression Analysis aims to determine the effect of self-efficacy on employee performance with organizational commitment moderation which can be seen in Table 3 below.

Table 3 - MRA Results

\begin{tabular}{|c|c|c|c|c|}
\hline \multirow{2}{*}{ Variable } & \multicolumn{2}{|c|}{ Regression Coefficient } & \multirow[b]{2}{*}{$\mathrm{t}$} & \multirow[b]{2}{*}{ Sig } \\
\hline & & Std. error & & \\
\hline$\overline{\text { (constant) }}$ & 22,268 & 0.417 & 53,422 & .000 \\
\hline Self-efficacy & 1,715 & 0.286 & 6,002 & .000 \\
\hline Organizational commitment & 0.709 & 0.292 & 2,425 & .017 \\
\hline \multirow{3}{*}{\multicolumn{5}{|c|}{$\begin{array}{l}\text { Dependent variable: Employee performance } \\
\text { F Statistics: } 21,282\end{array}$}} \\
\hline & & & & \\
\hline & & & & \\
\hline$R^{2}: 0.607$ & & & & \\
\hline
\end{tabular}

The value of the coefficient $\beta_{1}$ obtained is 1.715 indicating that the self-efficacy variable is positive, which means that self-efficacy can improve employee performance. The coefficient $\beta_{2}$ value obtained is 0.709 , indicating the variable organizational commitment to employee performance. This means that the higher is the commitment of organizational, the performance of employees increase as well. The value of the coefficient $\beta_{3}$ obtained is 0.827 , indicating that the interaction between self-efficacy variables and organizational commitment to employee performance is positive so that it can moderate employee performance. This means that the interaction of organizational commitment with self-efficacy can strengthen the effect of self-efficacy in improving employee performance.

The results of the $\mathrm{F}$ statistical test (Table 3 ) show the results of the significance value of 0.000 which is smaller than the level of $\alpha=0.05$. This means that self-efficacy and organizational commitment simultaneously have a significant effect on employee performance. This indicates that the model used in this study is reasonably interpreted. The t. test analysis shows that the regression coefficient $X$ is 1.715 with a significance level of 0.000 , smaller than the real level $\alpha=0.05$. This shows that self-efficacy has a positive and significant effect on employee performance. The result of t. test calculation shows that the regression coefficient $M$ is 0.709 with a significance level of 0.017 which is smaller than the real level $\alpha=0.05$. This shows that organizational commitment has a positive and significant effect on employee performance. The results of the t-test calculation (Table 3 ) shows that the regression coefficient value $|Z X M|$ is 0.827 with a significance level of 0.038 , which is smaller than the real level $\alpha=0.05$. This shows that the organizational commitment of employees can directly strengthen the effect of self-efficacy on employee performance. Based on the $R$ square model value of 0.607 or 60.7 percent, it means that 60.7 percent of the variation in employee performance can be explained by the variables in the model, namely self-efficacy and organizational commitment.

\section{DISCUSSION OF RESULTS}

Sultan and Tareen (2014) define self-efficacy as a person's belief in their work to complete tasks within a certain period of time. The self-efficacy is a positive behavior for the purpose of the organization in which employees with good self-efficacy can handle the emotions well, while employees who have a poor self-efficacy only worrisome issues that the job will fail (Ardanti and Rahardja, 2017). Efficacy is the belief of individuals of their selfcapabilities to perform task well despite of many obstacles. On the other hand, individuals 
who are not sure of their ability to work will certainly not be able to do their job well (Noviandari and Kawakib, 2016). The partial test results show that self-efficacy has a significant effect on employee performance (Judge et al., 2017; lis and Yunus, 2016). Research by David et al. (2016) finds that the important step of management is by maintaining some talented employees in the organization because they are believed to be a major investment and has reasonable factor of why organizations need to maintain them in the organization.

Saraswati et al. (2017) describe the self-efficacy as someone who has the ability to work in the environment at hand. According to Silvia et al. (2010), self-efficacy and job have become one unit; hence, if people lose their job, their individual sense of confidence can be decreased. Lunenburg (2011) states that self-efficacy can be affected by a number of factors, among others, how much people trust themselves in achieving the level of difficulty in the workforce, the strengths and weaknesses of the confidence in their abilities, and the extent to which the expectations in general the whole situation they face. Research conducted by Salman et al. (2016) shows that self-efficacy has a significant effect on employee performance. It is also said that self-efficacy has a significant relationship with work performance factors. This research is in line with Noviawati (2016), which states that self-efficacy has a significant effect on employee performance. The test results of hypothesis also show that self-efficacy significantly affects the performance of the employee (Tims et al., 2014). The self-efficacy itself plays an important role in improving the performance of employees (Robbins and Judge, 2012: 98). The results of this study are in accordance with Iroegbu (2015) who mentions that self-efficacy developed by organizations has a significant effect in improving employee performance. Marsudi (2017) states that self-efficacy development has a positive influence in improving employee performance.

The results of hypothesis test also show that organizational commitment has a significant effect on retaining employees. Agarwal, (2020) informs that an employee who has high organizational commitment tends to stay in the organization considering his role in helping the organization to achieve its goals. The partial test results also inform that organizational commitment has a significant effect on employee performance. Siagian (2013: 112) states that a workforce who has organizational commitment is very important in employee participation which can support organizational profitability. The organizational commitment is the nature of the employees who have a sense of awareness by showing a good performance against the organization and always maintain the progress of the organization. A number of studies have stated that employees' organizational commitment to the organization has a significant effect on improving employee performance (Maria, 2015: Yulan, 2017).

The results of hypothesis tested in this study show that organizational commitment moderates the effect of self-efficacy on employee performance. Expectancy Theory explains that each employee will tend to do their job based on the organizational commitment they have supported by their mental and attitude which make them have positive value or selfefficacy so that they can perform their jobs well. The results of the research by Pasha et al. (2017) finds that organizational commitment is able to significantly moderate the influence of self-efficacy on employee performance. Yulan's research findings (2017) state that organizational commitment is able to strengthen the positive relationship of self-efficacy in improving employee performance.

\section{CONCLUSION}

Based on the discussion of the research, it can be concluded that self-efficacy has a significant effect on employee performance meaning that the success of the self-efficacy can effectively improve the performance of employees. Organizational commitment has a significant effect on employee performance. This means that high employee commitment to the organization plays an important role in improving employee performance. The findings of this study inform that organizational commitment is able to significantly strengthen the effect of self-efficacy on employee performance. Employees who have high organizational 
commitment can better support the implementation of self-efficacy so as to improve employee performance.

The implication of this research indicates that management can provide a more conducive inner atmosphere to employees; hence, it can increase self-efficacy because there are still some cases of low attitude of employees who can do multitasking at once. A leader is expected to give motivation to restore the spirit of the work of subordinates, such as the sense of understanding the situation of today's work environment by considering the needs, requirements that support employees in work so that employees want to work with great enthusiasm. Management must pay attention to an indication of the employees who do not want to be involved in developing their department by helping their colleagues because the job base is not structured well that makes employees feel overwhelmed. Management is expected to instill an attitude of belonging (like working because of a sense of care for the organization) and loyalty to the organization; therefore, employees feel that they are working with financial rewards and benefits. Moreover, in improving employee performance, they must pay attention to the problems faced by employees at this time regarding work tasks that are not yet fully balanced, such as the huge number of room orders from tourists that causes the employees need to work overtime. A number of things must be anticipated by the organization by adjusting work hours during the high season and the business experienced by employees; hence, the employees can be more enthusiastic and able to improve performance.

\section{REFERENCES}

1. Ardanti, D. M., \& Rahardja, E. (2017). Pengaruh Pelatihan, Efikasi Diri and Keterikatan Karyawan Terhadap Kinerja Karyawan (Studi pada Patra Semarang Hotel \& Convention). Diponegoro Journal of Management, 6(3), 165-175.

2. Aboramadan, M., Albashiti, B., Alharazin, H., \& Dahleez, K. A. (2020). Human resources management practices and organizational commitment in higher education. International Journal of Educational Management.

3. Agarwal, N. (2020). A Study at organizational commitment of educator in school. Agarwal, Nidhi and Jaiswal, Sushma,(January 2019)."A Study at organizational commitment of educator in school". International Journal of Multidisciplinary Education and Research, 4(1), 39-41.

4. Bandura, A. (1991). Self Efficacy Mechanism in Psychological and Health-Promoting Behavior. New Jersey: Prentice Hall.

5. Berry, C. R. (2020). Developments in Personnel/Human Resources Management in State. Handbook of State Government Administration, 177.

6. Brown, S. P., Jones, E., \& Leigh, T. W. (2005). The attenuating effect of role overload on relationships linking self-efficacy and goal level to work performance. Journal of Applied Psychology, 90(5), 972-979.

7. Çetin, F., \& Aşkun, D. (2018). The effect of occupational self-efficacy on work performance through intrinsic work motivation. Journal of Management Research Review, 7(6), 1-18.

8. Dessler, G. (2006). Manajemen Sumber Daya Manusia, Jilid 2 Edisi 7. Jakarta: Prehallindo.

9. Dian, R, N. (2016). Pengaruh Self Efficacy Terhadap Kinerja Karyawan dengan Motivasi Sebagai Variabel Intervening (Studi Pada Karyawan Dividi Finance and Divisi Human Resource PT. Coca-cola Distribution Indonesia Surabaya). Jurnal IImu Manajemen (JIM), 4(3), 1-12.

10. Diamantidis, A. D., \& Chatzoglou, P. (2019). Factors affecting employee performance: an empirical approach. International Journal of Productivity and Performance Management.

11. Downes, P. E., Crawford, E. R., Seibert, S. E., Stoverink, A. C., \& Campbell, E. M. (2020). Referents or role models? The self-efficacy and job performance effects of perceiving higher performing peers. Journal of Applied Psychology. 
12. Ghozali, I. (2011). Aplikasi analisis multivariate dengan program IBM SPSS 19. Semarang: Badan Penerbit Universitas Diponegoro.

13. Hasibuan, M. S. (2016). Manajemen sumber daya manusia. Jakarta: PT. Bumi Aksara.

14. lis, E. Y., \& Yunus, M. (2016). Job Satisfaction as an Intervening Variable of SelfEfficacy and Employee Performance. International Journal of Academic Research in Business and Social Sciences, 6(7), 284-298.

15. Iroegbu, M. N. (2015). Self-efficacy and work performance: A theoretical framework of Albert Bandura's model, review of findings, implications and directions for future research. Psychology and Behavioral Sciences, 4(4), 170-173.

16. Jeffrey, A, G., Kevin, C, T, K., Deborah, C. W. (2017). Pengaruh Self Efficacy Terhadap Kepuasan Kerja and Kinerja Karyawan di Hotel Maxone Dharmahusada, Surabaya. Jurnal Manajemen and Kewirausahaan, 3(5), 135-149.

17. Judge, T. A., Jackson, C. L., Shaw, J. C., Scott, B. A., \& Rich, B. L. (2007). Self-efficacy and work-related performance: The integral role of individual differences. Journal of applied psychology, 92(1), 107-127.

18. Kreitner, R., and Kinicki, A. (2014). Perilaku Organisasi. Edisi 9. Buku 1. Jakarta: Salemba Empat.

19. Kim, B., \& Christopher G. N. (2018). The Moderating Effect of Supervisory Support on the Self-Efficacy Work-Performance Relationship. International Journal of Psychology and Behavioral Sciences. 28(3), 164-173

20. Laura, L. P. (2017). Exploring The Power of Self-Efficacy at Work: Some Empirical Studies from the Social Cognitive Perspective. International Journal of Business and Economics, 19(3), 12-98

21. Lunenburg, F. C. (2011). Self-efficacy in the workplace: Implications for motivation and performance. International journal of management, business, and administration, 14(1), 1-6.

22. Luthans, F. (2011). Perilaku Organisasi, Edisi kesepuluh. Yogyakarta: Penerbit Andi Offset.

23. Machmud, S. (2018). The influence of self-efficacy on satisfaction and work-related performance. International Journal of Management Science and Business Administration, 4(4), 43-47.

24. Maria, S. (2014). The Moderating Role of Self-Efficacy in the Organizational CultureTraining Transfer Relationship. International Journal of Training and Development, 11(2), 1-15.

25. Marsudi, L. (2017). Self Efficacy and Achievement Motivation on Performance with Perceived Organizational Support Moderation. Journal of Advances in Intelligent Systems Research, 13(1), 81-85.

26. Meyer, J. P., \& Allen, N. J. (2004). TCM employee commitment survey academic users guide 2004. London, Ontario, Canada: The University of Western Ontario, Department of Psychology.

27. Mustika, I. N., \& Widyawati, S. R. (2020). The Influence of Employee Engagement, Self Esteem, Self-Efficacy On Employee Performance In Small Business. International Journal of Contemporary Research and Review, 11(04), 21771-21775.

28. Mustafa, G., Glavee-Geo, R., Gronhaug, K., \& Saber Almazrouei, H. (2019). Structural impacts on formation of self-efficacy and its performance effects. Sustainability, 11(3), 860.

29. Noviandari, H., \& Kawakib, J. (2016). Teknik Cognitive Restructuring untuk Meningkatkan Self Efficacy Belajar Siswa. Jurnal Psikologi: Jurnal IImiah Fakultas Psikologi Universitas Yudharta Pasuruan, 3(2), 76-86.

30. Noviawati, D. R. (2016). Pengaruh Self Efficacy Terhadap Kinerja Karyawan Dengan Motivasi Sebagai Variabel Intervening (Studi Pada Karyawan Divisi Finance and Divisi Human Resource Pt. Coca-Cola Distribution Indonesia, Surabaya). Jurnal Manajemen, 4(3), 1-12.

31. Pasha, A. T., Hamid, K. A., \& Shahzad, A. (2017). Moderating effect of self-efficacy and impact of career development practices on career success under the mediating role of 
career commitment in the insurance sector of Pakistan. The Journal of Internet Banking and Commerce, 22(1), 1-22.

32. Putri, P. E. V., \& Wibawa, I. M. A. (2016). Pengaruh Self-Efficacy and Motivasi Kerja terhadap Kepuasan Kerja Pegawai Bagian Perlengkapan Sekretariat Kabupaten Klungkung. E-Jurnal Manajemen Universitas Udayana, 5(11), 7339-7365.

33. Robbins, S.P., and Judge. (2012). Perilaku Organisasi, Edisi Kedua belas, Jakarta: Salemba Empat.

34. Salman, M., Khan, M. N., Draz, U., lqbal, M. J., \& Aslam, K. (2016). Impact of SelfEfficacy on Employee's Job Performance in Health Sector of Pakistan. Americacn Jornal of Bussiness and Society, 1(3), 136-142.

35. Saraswati, A. A. N. D., Dewi, I. M., \& Piartini, P. S. (2017). Pengaruh efikasi diri terhadap kinerja dengan dukungan organisasional sebagai pemoderasi. E-Jurnal Ekonomi and Bisnis Universitas Udayana, 2257-2286.

36. Siagian, S. (2013). Manajemen Sumber Daya Manusia. Jakarta: Penerbit Bumi Aksara.

37. Silvia, P., Maria Luisa, F., Francesco, A., \& Michele, V. (2010). Work Self-Efficacy Scale and Search for Work Self-Efficacy Scale: A Validation Study in Spanish and Italian Cultural Contexts. Revista de Psicología Del Trabajo Y de Las Organizaciones, 26(3), 201-210.

38. Stevani, S., \& Jafar, S. (2017). Pengaruh Self Efficacy and Self Esteem terhadap Kinerja Individual Karyawan PT. Finnet Indonesia. Jurnal Proceeding of Management, 4(1), 336345.

39. Sugiyono. (2017). Metode Penelitian Bisnis. Bandung: CV Alfabeta.

40. Sultan, S., \& Tareen, N. (2014). Examining the Effect of Self Efficacy on Employees' Performance through Cultural Intelligence. Journal of Asian Development Studies, 3(2), 41-49.

41. Suyana, U, M. (2016). Buku ajar Aplikasi Analisis Kuantitatif. Denpasar: Fakultas Ekonomi Universitas Udayana.

42. Tims, M., Bakker, A. B., \& Derks, D. (2014). Daily job crafting and the self-efficacyperformance relationship. Journal of Managerial Psychology, 29(5), 490-507.

43. Vroom, V. H. (1964). Work and Motivation. New York: John Willey \& Son, Inc.

44. Wulantika, L., \& Ayuningtias, N. (2020). Effect of Career Planning and Self-Efficacy of the Performance of Employees. In International Conference on Business, Economic, Social Science, and Humanities-Economics, Business and Management Track (ICOBEST-EBM 2019) (pp. 100-103).

45. Yulan, I, B. (2017). Pengaruh Self Efficacy, Budaya Organisasi and Motivasi Kerja Terhadap Komitmen Organisasi. Jurnal Manajemen and Kewirausahaan, 12(1), 114-138. 